who invented the formula assumed that multiple infections in the same patient were independent, which is certainly not realistic for the majority of NIs (in our patient group, however, multiple NIs were very rare).

Secondly, we considered an infection as prevalent as long as the patient was symptomatic or received antimicrobial therapy. This means that, due to differences in the typical duration of antimicrobial treatment in the various hospitals, the chances of a patient being diagnosed as nosocomially infected were not the same in all hospitals.

Third, values for LA, LN, and INT in the discharged patients were calculated from the incidence study data. A number of patients (495 patients, or $17.2 \%$ ) already were hospitalized when the surveillance period started. In this group, it was not clear whether the NIs recorded were their first. It may thus be possible that the INT for those patients was incorrect.

Another limitation might be the rather short 3week interval between the different prevalence studies; patients with long-lasting infections already may have been considered in previous prevalence investigations. However, only one patient was recorded in two prevalence studies, and the second diagnosis of NI was due to a new infection.

Different investigators recording NI for the incidence and prevalence study could have been another source of interconvertibility problems. ${ }^{15,16}$ However, the same investigators recording NI for our study also recorded NI in the prevalence and incidence study in the eight hospitals; thus, an investigator effect in diagnosing NI due to varying sensitivity and specificity could not emerge.

Despite the limitations mentioned, the estimate computed by the method of Rhame and Sudderth is confirmed by this study. However, we do not recommend converting prevalence rates to incidence rates or vice versa, even if it is theoretically possible.

\section{REFERENCES}

1. Freeman J, Hutchison G. Prevalence, incidence and duration. Am J Epidemiol 1980;112:707-723.

2. Freeman J, McGowan JJ. Day-specific incidence of nosocomial infection estimated from a prevalence survey. Am J Epidemiol 1981;114:888-901.

3. Rhame F, Sudderth W. Incidence and prevalence as used in the analysis of the occurrence of nosocomial infection rates. $A m I$ Epidemiol 1981;113:1-11.

4. French G. Repeated prevalence surveys. In: Emmerson A, Ayliffe G, eds. Clinical Infectious Diseases. London, UK: Baillière; 1996:179-195.

5. Garner JS, Emori WR, Horan TC, Hughes JM. CDC definitions for nosocomial infections. Am J Infect Control 1988;16:128-140.

6. Horan TC, Gaynes RP, Martone WJ, Jarvis WR, Emori TG. CDC definitions of surgical site infections: a modification of $C D C$ definitions of surgical wound infections. Infect Control Hosp Epidemiol 1992;13:606-608.

7. Gastmeier P, Geffers C, Daschner F, Ruiden H. Diagnostic training in the surveillance of nosocomial infections: what is feasible and useful? Zent.bl. Hyg. Umweltmed. 1998;201:153-166.

8. Gastmeier P, Kampf G, Wischnewski N, Schumacher M, Daschner F, Ruiden $\mathrm{H}$. Importance of the surveillance method-various national prevalence studies on nosocomial infections and limits of comparison. Infect Control Hosp Epidemiol 1998;19:661-667.

9. Vincent J-L, Bihari D, Suter PM, Bruning HA, White J, Nicolas-Chanoin $\mathrm{MH}$, et al. The prevalence of nosocomial infections in intensive care units in Europe. JAMA 1995;274:639-644.

10. Mayon-White R, Ducel G, Kereselidze T, Tikomirov E. An international survey of the prevalence of hospital-acquired infection. J Hosp Infect 1983;11(suppl A):43-48.

11. French GL, Wong SL, Cheng AFB, Donnan S. Repeated prevalence surveys for monitoring effectiveness of hospital infection control. Lancet 1989;28:1021-1023.

12. French GL, Cheng AF. Measurement of the costs of hospital infection by prevalence surveys. $J$ Hosp Infect 1991;18:65-72.

13. National Nosocomial Infections Surveillance System. National Nosocomial Infections Surveillance (NNIS) Report, Data Summary from October 1986-April 1997, issued May 1997. Am J Infect Control 1997;25:477-487.

14. Delgado-Rodríguez M, Cueto Espinar A, Rodríguez-Contreras Pelayo R Galvez Vargas R. A practical application of Rhame and Sudderth's formula on nosocomial infection surveillance. Rev.Epidém. et Santé Publ. 1987;35:482-487.

15. Emori TG, Edwards JR, Culver DH, Sartor C, Stroud LM, Gaunt E, et al. Accuracy of reporting nosocomial infections in intensive-care-unit patients to the National Nosocomial Infections Surveillance System: a pilot study. Infect Control Hosp Epidemiol 1998;19:308-316.

16. Gastmeier P, Kampf G, Hauer T, Schlingmann J, Schumacher M, Daschner F, et al. Experience with two validation methods in a prevalence survey on nosocomial infections. Infect Control Hosp Epidemiol 1998;19:668-673.

\title{
Transmission of HBV in a Nursing Home
}

\section{Gina Pugliese, RN, MS \\ Martin S. Favero, PhD}

Japanese researcher Mizokami and colleagues conducted a seroepidemiological study of hepatitis B virus (HBV) infection to investigate the seroprevalence of hepatitis B surface antigen ( $\mathrm{HBsAg}$ ) and the transmission routes of HBV infection among residents of a nursing home for the elderly. HBV serum markers were examined in 119 residents and 71 healthcare workers in the institution, and in the control group of 1,330 healthy subjects from the same geographical area.
HBsAg was detected in $6(5 \%), 0$, and $20(1.5 \%)$ residents, healthcare workers, and healthy subjects, respectively. Four residents (A-D) who had HBV DNA in the serum were studied by molecular evolutionary analysis. The strains derived from residents $A, B$, and $D$ were clustered within a close range of evolutionary distances. Residents B and D, who were not positive for $\mathrm{HBsAg}$ at the time of admission to the institution, subsequently became HBsAg-positive asymptomatic carriers. These results suggested intrainstitutional transmission of $\mathrm{HBV}$ in the nursing home for the elderly and confirmed that the source of trans- mission of $\mathrm{HBV}$ to residents $\mathrm{B}$ and $\mathrm{D}$ was resident $\mathrm{A}$, who was positive for $\mathrm{HBsAg}$.

The authors recommend that residents in a nursing home for the elderly should be considered a high-risk group for HBV infection and should be vaccinated against HBV.

FROM: Sugauchi F, Mizokami M, Orito E, Ohno T, Kato H, Maki M, et al. Hepatitis $B$ virus infection among residents of a nursing home for the elderly: seroepidemiological study and molecular evolutionary analysis. J Med Virol 2000; 62:456-462. 